\title{
Gennadii Korolov
}

\section{"Anticolonial Intellectual" Anton Łuckiewicz and "Hybrid Nationalist" Otto Eichelman. A Comparative Study of Federalist Utopias*}

Zarys treści: Autor porównuje idee federacyjne białoruskiego działacza narodowego Antona Łuckiewicza, czwartego premiera Białoruskiej Republiki Ludowej, i ukraińskiego prawnika Ottona Eichelmana, jednego z autorów tekstu Konstytucji Ukraińskiej Republiki Ludowej. Przedstawia ich założenie o rozwoju BRL i URL w ramach przebudowy Europy Wschodniej.

Outline of content: The author compares the federalist ideas developed by Anton Euckiewicz, prime minister of the Belarusian People's Republic (1918-1920), and the Ukrainian lawyer Otto Eichelman, the author of the Constitution of the Ukrainian People's Republic. In the article, he presents their opinions on the development of the Belarusian and Ukrainian People's Republics in the reconstruction of Eastern Europe.

Słowa kluczowe: Anton Łuckiewicz, Otto Eichelman, białoruskie idee federacyjne, intelektualista antykolonialny, nacjonalista hybrydowy, Europa Wschodnia, Imperium Rosyjskie

Keywords: Anton Łuckiewicz, Otto Eichelman, Belarusian federalist ideas, postcolonial intellectual, hybrid nationalist, Eastern Europe, Russian Empire

\section{Introduction}

The protagonists of this article are two national and revolutionary activists. Both represented failed attempts to create nation states: Belarusian and Ukrainian respectively. Their concepts, ideas and federational projects within the framework of

* I would like to express my gratitude to the Krzysztof Skubiszewski Foundation, which provided me with an opportunity to conduct my research in Poland, and to Professor Dorota Michaluk (Nicolaus Copernicus University in Toruń) for her invaluable contribution and corrections to this text. 
creating a national ideology can be examined in the context of the history of "mutual interactions" (according to the German historian Klaus Zernack), ${ }^{1}$ as a transfer of ideas which developed in response to the existing imperial order in Eastern Europe.

The first of them, Anton Euckiewicz (1884-1942), was a literary critic and publicist, who after the proclaiming of the Belarusian People's Republic (BNR) became its fourth prime minister and a foreign minister in the years $1918-1920 .^{2}$ This fact from his life is important for understanding the problems of the emergence of the Belarusian political elite. He was also the author of a project for reconstruction of Eastern Europe. The other, Otto Eichelman (1854-1943), was a well-known lawyer and a specialist in international law, who joined the Ukrainian nationalist movement. During the Hetmanate of 1918 and the Directorate of the Ukrainian People's Republic he served as Deputy Minister of Foreign Affairs. ${ }^{3}$ As the author of the idea of federational Ukraine, he was an active participant in the debate on Central and Eastern Europe as an area of "new" nations. Both activists authored federational projects, which were never completed and were rather utopian in nature.

The purpose of this article is an attempt to comparatively discuss the federalist concepts represented by known activists of the Belarusian and Ukrainian national movements. A critical analysis of these visions will focus on the question of whether they included interactions between the two countries, and their similarity in relation to "otherness". Clearly, the "other" was the Russian Empire. This is precisely where the contradiction lies, because Russia, like Austria, was seen as a nation-state, and not as a multinational empire. This was how national activists justified the colonial status of their countries.

An important issue is also the development of a colonial and nationalistic consciousness among activists of the Ukrainian and Belarusian national movement, as well as how they perceived their countries within the Empire and constructed their future as nation states. The German historian Jörn Leonhard described this situation in the following way: according to him,

The outcome of the war in 1918 led to a particular narrative in historiography regarding the somehow inevitable end of traditional and autocratic empires on the European continent. According to this interpretation, the First World War only completed a process which had been obvious already prior 1914: Multi-ethnic empires seemed to be anachronistic

${ }^{1}$ R. Traba, "Historia wzajemnych oddziaływań - (niedoceniany) paradygmat w nadaniu przeszłości. Wprowadzenie", in: Historie wzajemnych oddziaływań, ed. R. Traba, Berlin-Warszawa, 2014, pp. 7-18.

2 Cf. A. Bergman, “Antoni Łuckiewicz (1884-1946). Szkic biograficzny”, Przegląd Historyczny, 65 (1974), no. 4, p. 667-695.

3 Cf. Г.О. Корольов, “Українська історія Отто Ейхельмана. Імперська лояльність та служіння ‘іншій’ або ‘своїй’ нації”, Архіви України, 2014, по. 1, pp. 156-167. 
political entities, old prisons of young nations, which could have survived only by the violent suppression of national movements and ethnic groups. ${ }^{4}$

However, this general reasoning does not explain the true situation. Before World War I, and after 1905, a somewhat opposite process was taking place in Russia, where the needs of the peoples living in Russia were taken into account and ethnic policies mitigated; in many ways, a similar national policy was also applied in Austro-Hungary.

The Great War (1914-1918) and the Russian Revolution determined the development of multiple variants of the federational idea in both Belarus and Ukraine. It should be emphasised that federalism was not an original concept in Łuckiewicz and Eichelman's work, rather they used it as an alternative to the imperial system, and one of the popular slogans in the socialist environment of Western Europe. It is known that this theory had been formulated previously and presented by various European intellectuals. In $19^{\text {th }}$ century, federalism became a tool of political struggle, the ideology of the tactics for creating a nation state in terms of "ethnographic determinism". Federalism was not a "special" current of political thought in the Romanov empire in the $19^{\text {th }}$ and the beginning of the $20^{\text {th }}$ centuries, as the creators of the various projects of transforming the great Empire did not have contact with each other, ${ }^{5}$ although they shared a common vision of democratic Russia.

In general, the interest in federalism reflects a general trend among the representatives of the political thought of the "new" nations of the Central and Eastern Europe. For the Ukrainian and Belarusian activists, justifying the federalist vision had a dimension of justifying the political struggle against the Russian Empire.

The development of the Belarusian national movement differed from the Ukrainian one in several important aspects. The first feature was the difficult process of shaping the Belarusian national identity. The Austrian historian Andreas Kappeler believes that the "ethnic and linguistic identity, and religious identification were closely interlinked". ${ }^{6}$ The separateness from Poles and Russians itself was religious in nature, in Russia associated with Orthodox Christianity, and in Poland with Catholicism. The approach of the German army resulted in the escape of Orthodox Belarusians, and often in their forced evacuation from indigenous lands to the East, ordered by the Russian army and administration. ${ }^{7}$ The second

${ }^{4}$ J. Leonhard, "Multi-Ethnic Empires and Nation-building: Comparative perspectives on the Late Nineteenth Century and the First World War", in: Nationalizing Empires, ed. S. Berger, A. Miller, Budapest - New York, 2015, p. 630.

${ }^{5}$ М. фон Хаген, “История России как история империи. Перспективы федералистского подхода", in: Российская империя в зарубежной историографии. Работы последних лет: Антология, Москва, 2005, р. 26.

6 А. Каппелер, Россия - многонациональная империя. Возникновение. История. Распад, Москва, 2000, p. 210.

7 D. Michaluk, Białoruska Republika Ludowa 1918-1920. U podstaw białoruskiej państwowości, Toruń, 2010, p. 132. 
aspect was the myth of the Grand Duchy of Lithuania (GDL), which was not connected with the Polish project of the rebirth of the First Polish Republic. It was the idea of the Belarusian revival of the GDL that was linked with the national idea and the concept of political unity and community of Lithuania and Belarus. The Polish historian Dorota Michaluk believes that the publication of the newspaper "Homan" ("Hubbub") edited by Vaclau Lastouski and Łuckiewicz brothers, as well as creating the GDL confederation was an attempt to revive the nationalist idea and a response to the concept of Mitteleuropa. ${ }^{8}$ The Euckiewicz s offered this concept as their alternative to the Central European "bulwark" against the imperial threat from the East. Indeed, their concept of the GDL included this option as a counter-proposal in order to organise the area "between Germany and Russia".

At the beginning of the $20^{\text {th }}$ century, there was no active, growing national movement on Belarusian territories. Many researchers believe that this was linked with the characteristics of Belarusians' mentality and folk identity. ${ }^{9}$ The well-known Polish writer and political activist Leon Wasilewski wrote about Belarusians as people who "do not stand a comparison with state nations, although some features bring them close to some" ${ }^{10}$ He then stated that Belarusians do not have their own state traditions. ${ }^{11}$ However, Belarusian national activists at that time were already appealing to two state concepts, seeing the beginnings of their statehood in the Principality of Polotsk and, indeed, in the GDL.

On the Ukrainian territories belonging to the empires of the Romanovs and Habsburgs, very similar processes were taking place, although the nation-forming development progressed faster. To understand the modern Ukrainian nationalism, it is worth looking at the Ukrainian People's Republic and the West Ukrainian People's Republic (1918) from trans-nationalist positions. After 1918, Ruthenians, Little Ruthenians, and members of the Uniate and Orthodox churches eventually became Ukrainians. The Ukrainian identity won thanks to the enormous amount of promotion of the peasant culture and a national narrative, around which the intelligentsia formed as a national elite. Analysing the causes of the revolution, the Ukrainian historian Vladislav Verstiuk determined that the universal national consciousness until 1917 should be written about with great care. ${ }^{12}$

However, a tool to implement these changes was the ideas which appeared in the circles of opposition against the Russian Empire. All of this was reflected in various federalist projects, which initially emerged as an attempt to justify the

8 Ibid., p. 141.

9 Д. Міхалюк, “Пэр Андэрс Рудлінг, Ад Вялікага Княства Літоўскага да Беларускай Народнай Рэспублікі ідэя беларускай дзяржаўнасці падчас нямецкай акупацыі беларускіх земляў у 1915-1919 гадах", Журнал беларускіх даследаванняў, 7 (2014), no. 2, pp. 7-42.

10 L. Wasilewski, "Białoruś i ruch białoruski”, Przegląd Współczesny, 3 (1924), no. 26.

11 Ibid.

12 В. Верстюк, В. Солдатенко, “Революції в Україні: політико-державні моделі та реалії (19171920)”, in: Політична історія України ХХ століття. У 6-ти т., vol. 2, Київ, 2003, p. 456. 
imperial system. Later on, these projects were considered an alternative to the Empire. Of course, the popularity of these ideas was determined by the prevalence of Marxism and nationalism.

\section{Anton Łuckiewicz "between Germany and Russia"}

The Belarusian journalist Anton Łuckiewicz was born in 1884 in the Lithuanian town of Šiauliai. ${ }^{13} \mathrm{He}$ was of noble descent. His political world-view was shaped within the Polish-Belarusian-Lithuanian sphere. His choice of the Belarusian identity was a form of opposing the Empire, and of a belief in the possibility of renewal for the Grand Duchy of Lithuania. He studied at the Faculty of Mathematics and Physics of Saint Petersburg University and, later on, a part-time law degree at the University of Tartu (then Dorpat). From 1903, he participated in the Belarusian Revolutionary Hramada; however, the following year he was arrested for political reasons and was kept under police surveillance. ${ }^{14}$ Despite this, he continued his opposition activities. At the end of 1905, he participated in the first congress of the Hramada, at which he was elected for its governing bodies.

During World War I, Łuckiewicz lived in Vilnius, where together with his brother he founded the newspapers Nasha Dolya, followed by Nasha Niva, published in Belarusian. After the occupation of Vilnius by the German army in September 1915, he worked in the Belarusian Society for the Aid of the Victims of War, remaining politically active. In the years 1915-1917, he and his brother Ivan played a major role in the Belarusian People's Committee. ${ }^{15}$ There, Łuckiewicz promoted the idea of recreating the Grand Duchy of Lithuania in the form of a confederation of Belarusian and Lithuanian territories. ${ }^{16} \mathrm{He}$ wrote that "in Vilnius we stood on the ground of state independence within the Belarusian-Lithuanian federation". ${ }^{17}$

Until the beginning of the Great War, Belarusian nationalists clung to the federation principle with a free Belarus and free neighbours. ${ }^{18}$ Also, from 1916 the Association for Independence and Indivisibility of Belarus was operating in Vilnius, unrelated to the brothers Łuckiewicz. Federational ideas have been politically formulated in the resolution of the Confederation of the Grand Duchy of Lithuania in the summer of 1915. Previously, similar projects were also presented by Ukrainian activists, e.g. the prominent historian Mykhailo Hrushevsky,

\footnotetext{
13 Bergman, Antoni Łuckiewicz, p. 667.

14 Ibid., p. 668.

15 Міхалюк, Пэр Андэрс Рудлінг, р. 16.

16 Ibid., p. 16.

17 А. Луцкевіч, “Палітычныя лёзунгі беларускага руху”, in: id., Да гісторыі беларускага руху, Смаленск, 2015, р. 97.

18 Ibid.
} 
who argued the possibility of a federalist remodelling of Russia and autonomy of Ukrainian territories. ${ }^{19}$

In December 1915, several Belarusian-Lithuanian meetings took place, in which the issue of the future of the Belarusian and Lithuanian lands occupied by the German army was discussed. ${ }^{20}$ As Łuckiewicz himself wrote, as a result of these a decision was made to "notify the world [about it] before carrying out the fact of renewing the Grand Duchy of Lithuania, which existed until the union with Poland". ${ }^{21}$ In order to implement this proposal, in February 1916 the GDL confederation issued the act Грамадзяне!, signed by the brothers Łuckiewicz, Vaclau Lastouski and Dominik Syamashko. The idea of the independent GDL was considered in the context of the political changes during World War I. ${ }^{22}$ Naturally, the resolution was an attempt to interest Germans in recognising the GDL's statehood. For this reason, the possible participation of the GDL in the alliance of the Central Powers was mentioned.

It was while carrying out this political proposal that Łuckiewicz prepared a paper entitled “Злучаныя Штаты ад Балтыкі да Чорнага мора"23 in order to present the Belarusian-Lithuanian stance at the conference in Lausanne. As it is known, the "congress of nations enslaved by Russia" was organised by Germans in the summer of 1916. Łuckiewicz's paper was taken there by his brother Ivan and Vaclau Lastouski.

In the text, Łuckiewicz tried to formulate the idea of "united states" in the area between the Baltic and the Black Sea on the basis of creating and recognising nation states, which would emerge after the fall of the Russian empire. He started with defining the Belarusian nation as a state nation even in the period of the GDL. ${ }^{24}$ Next, he wrote about the colonial oppression towards Belarusians and the discriminatory policy. These are the typical formulations used to assess the internal policies of the Romanov monarchy. A set of such arguments used by Łuckiewicz allows us to describe him as an "anti-colonial intellectual". He believed that the Belarusian nation formed owing to persecutions and assimilation policies on the part of the Russian Empire. For this reason, the subject of history was the empire, and the nation - only a passive object.

Indeed, in their writings and rhetoric the colonial intellectuals (both Ukrainian and Belarusian) approached "the nation" as the sense of the historical process.

19 С. М.С. Грушевский, Освобождение России и украинский вопрос. Статьи и заметки, Санкт-Петербург 1907, р. 301.

20 “Собственноручные показания А.И. Луцкевича. 30 октября 1939”, in: Луцкевіч, Да гісторы p. 231.

21 Ibid.

22 Lietuvos centrinis valstybės archyvas, f. 383, ap. 7, b. 56, 1. 53 (улётка Грамадзяне!, люты 1916).

23 А. Луцкевіч, “Рэфэрат Беларускае дэлегацыі на Лязанской канфэрэнцыі народаў Рacei”, in: id., Да гісторьі, pp. 78-81; А. Луцкевіч, “Злучаныя Штаты ад Балтыкі да Чорнага мора”, Свабода, 1990, nо. 2, рр. 5-7.

24 Луцкевіч, Рэфбрат Беларускае дэлегащьі, р. 78. 
They believed that their view was the most adequate in relation to the "trends" of the historical process. On this basis, it is rather easy to prove the trends and the arguments of the ideology of the Belarusian independence movement, as the vocabulary of its eminent personalities was based on the ideas about the empire and capitalism, such as personal discrimination, national assimilation, Russification, language dominion, colonial status, and Russia as "the prison of nations".

Euckiewicz analysed the federalist vision from 1905, when the Belarusian Revolutionary Hramada's slogan appeared claiming a "free Belarus as a democratic republic, federated with its neighbours". ${ }^{25}$ To strengthen this thesis in the political dimension, he used the idea of GDL as a common state for Belarusians and Lithuanians. Aside from this, however, he did not explain the differences between the dominant national projects, characteristic of the political organisations at the beginning of the $20^{\text {th }}$ century. At the same time, paying attention to the economic dimension, he wrote of the importance of contacts with Latvians, since the growth of Belarus depended on the access to the Baltic Sea. The situation was identical in the case of the Black Sea and Ukrainians. Overall, its interpretation was based on the idea of statehood. In this aspect, Łuckiewicz appears as a typical anti-colonialist in a Marxist dimension, who also counts on social liberation after the collapse of the empire.

On these grounds Euckiewicz constructs his idea of "the united states from the Baltic Sea to the Black Sea", within which the independent Belarus will be in a union with free neighbouring peoples, including Polish and Jewish residents of Belarus. ${ }^{26}$ In this concept of Euckiewicz, there was no Poland, and its implementation depended on one condition - the dissolution of the Russian Empire.

Further attempts to realise the idea of the GDL confederation continued also after the Bolshevik coup in October 1917. In December of the same year, at the meeting of the Lithuanian Bürys - Politine Valdyba and the Belarusian People's Committee (the brothers Łuckiewicz, Vaclau Lastouski), with active German support, the programme for creating the GDL confederation was passed: firstly, the independence of the territories of the former GDL and Courland from Russia; secondly, the rejection of the idea of a union with Poland; thirdly, the division of the state into three independent, autonomous units (Belarusian, Lithuanian, Latvian); finally, the capital should be in Vilnius, which would enter the Lithuanian part. ${ }^{27}$ However, this confederation project was not accepted by Germans in the end. ${ }^{28}$

25 Ibid., p. 79.

${ }^{26}$ Ibid., pp. 80-81.

27 Lietuvos Mokslų Akademijos Vrublevskų Biblioteka, Rankraščių skyrius, f. 21, b. 2069, 11. 7-8 (пратаколы беларускіх арганізацый 1917).

28 Ibid., 1. 7. 
In Memorial from 22 January 1918, Łuckiewicz treated the inclusion of Belarus and Lithuania to the Russian state as an act of violence, and considered the Grand Duchy as a dichotomous state, composed of Belarusian and Lithuanian parts. ${ }^{29}$

On 18 March 1918, he became a member of the Council of the Belarusian People's Republic. After the dissolution of the Hramada, he became one of the founders of the Belarusian Social Democratic Party. In September 1918, he was appointed by the Council of the Belarusian People's Republic as the chair of the People's Secretariat and the Secretary of Foreign Affairs (from October that year). Although none of the states officially recognised the Republic, in the autumn Euckiewicz hoped this would happen during the peace conference in Paris. ${ }^{30}$ At the beginning of December 1918, the government of the Republic, led by Łuckiewicz, moved to Vilnius, and on 27 December to Grodno.

In 1920, as the prime minister of the Republic, Anton Łuckiewicz published a brochure in Warsaw entitled The Eastern Question and Belarus under the pseudonym Wiesław Kalinowski, in which he presented the idea of how the "Eastern Question" should be solved. ${ }^{31}$ After the end of the war in this territory, "these nations and new state formations must be preserved which fate placed between the two broken, but already recovering giants Germany and Russia". ${ }^{32} \mathrm{He}$ called the idea of a "Slavic federation", as a project of a revival of Russia in its previous borders, fictional. ${ }^{33}$

In this work, he returned to the idea of a union of countries between the Baltic Sea and the Black Sea. However, it corresponded with the contemporary Polish vision of a confederation "from sea to sea" ${ }^{34} \mathrm{He}$ expanded the borders of the constructed space for countries in this part of the European continent. He added to his confederation project Czechoslovakia, Yugoslavia, and the Balkan countries. ${ }^{35}$ Indeed, he reinterpreted the idea of "Intermarium".

The Adriatic Sea appears here as one of the borders of the union. However, it is known that in those days the very same idea was popular among Polish elites. We could argue that such vision of Łuckiewicz 's was typical ideological epigonism. It changed his opinion about the role of Poland in Eastern Europe, as this country was interested in the creation of Belarusian statehood and separating it from Russia. ${ }^{36}$ Next, tuckiewicz repeated phrases characteristic of anti-colonial

29 D. Michaluk, "Premier Białoruskiej Republiki Ludowej Antoni Łuckiewicz wobec polskich i litewskich aspiracji do Wileńszczyzny i Grodzieńszczyzny”, Europa Orientalis. Studia z Dziejów Europy Wschodniej i Państw Bałtyckich, 2 (2010), p. 37.

${ }^{30}$ Michaluk, Białoruska Republika Ludowa, p. 339.

${ }^{31}$ W. Kalinowski, Kwestja Wschodnia a Białoruś, Warszawa, 1920, p. 14.

${ }^{32}$ Ibid., p. 4.

33 Ibid., p. 5.

${ }^{34}$ Cf. P. Okulewicz, Koncepcja „międzymorza” w myśli i praktyce politycznej obozu Józefa Piłsudskiego w latach 1918-1926, Poznań, 2001, p. 417.

35 Kalinowski, Kwestja Wschodnia, p. 6.

36 Ibid., p. 12. 
ideology, in the belief that "Russia without the Baltic Sea, without Belarus, without Ukraine, will not threaten anyone", all the more if a strong group of countries was to be formed there. ${ }^{37}$

Łuckiewicz's federalist vision was an attempt to find a state project in which Belarus would regain full independence. However, this would be possible if two conditions were met. The first was the idea of a joint state with Lithuania. The second - victory over Russian imperialism.

\section{Otto Eichelman "between the empire and new Russia"}

In the same period, the Kiev-based professor Otto Eichelman pursued an academic career, remaining in the position of loyalty towards the Russian imperial regime. A Baltic German by birth, he was born in 1854 in Georgiyevsky Khutor near St. Petersburg, and never took part in revolutionary activities. What is more, before the war he became a member of the constitutional commission under the direction of Tsar Nicholas II. Everything changed in his life after the fall of the autocracy.

During the Ukrainian Revolution (1917-1921) and in exile, Eichelman became one of the leading proponents of the "Ukrainian question". The question is: what influenced such a transformation of political consciousness, why did he choose the Ukrainian identity and sincerely believed in the future of the Ukrainian state? This issue could explain the phenomenon of fusing the German ethnic identity and Ukrainian political consciousness, and Eichelman's political activity during the period of Hetmanate in 1918 and the Ukrainian People's Republic. Eichelman can be described as "a hybrid nationalist". It was exactly this phenomenon that the American historian Mark von Hagen wrote about, analysing the processes of identity formation in the borderlands of the Romanov empire, which included Ukrainian and Belarusian territories; he was of the view that diverse situational and hybrid identities, characterised by plural loyalty, developed widely in those areas. ${ }^{38}$

At the beginning of the $20^{\text {th }}$ century, Eichelman was a well-known lawyer in Kiev, working as a professor at the Department of General History of Law and International Law, and in 1905 he became dean of the Faculty of Legal Studies at Saint Vladimir University. From 1908 to 1913 he served as director of the Kiev Commercial Institute and Rector of the Saint Vladimir University. He was active in various organs of local government, and in 1902 he was elected mayor of Kiev. ${ }^{39}$ In the ideological dimension, Eichelman belonged to the circle of liberal

37 Ibid., p. 14.

38 М. фон Хаген, “Империи, окраины и диаспоры. Евразия как антипарадигма для постсоветского периода", in: Новая имперская история постсоветского пространства, ed. И. Герасимова et al., Казань, 2004, p. 131.

39 Т.С. Осташко, “Ейхельман Отто Оттович”, in: Енциклопедія історії України, vol. 3: Е-Й, ed. В.А. Смолій, Київ, 2005, p. 672, http://www.history.org.ua/?termin=Eykhelman_O (access: 20 April 2016). 
activists, who suggested loyal principles for the improvement of the state order. The professor never expressed radical views and political extremism. We could suppose that he was a conformist, characterised by a specific imperial loyalty. In everyday life, he remained a typical academic, little preoccupied with issues of practical politics. ${ }^{40}$

During the Hetmanate of Pavlo Skoropadskyi, Eichelman became a member of the Trade and Industry Council, as well as a deputy of the Foreign Minister Dmytro Doroshenko. In the period of Directorate (1920-1922), he once again worked as a Deputy Foreign Minister, and a member of the Council of the Ministry of Culture. He also belonged to the Higher Legislative Council (19211922). In April 1922, he was appointed the director of the Ministry of Foreign Affairs of the Ukrainian People's Republic in exile. It is not surprising therefore that during his lectures at the Ukrainian Free University in Prague he publicly declared his Ukrainian identity. ${ }^{41}$ As an émigré, he was a member of the party Ukrainian People's Union, whose aim was to achieve Ukraine's independence by political means.

Eichelman was one of the key theorists of the constitutional order, becoming a co-author of the first acts and the Constitution. In his reflections, he drew on the concept of federalisation of Ukraine through creating independent administrative units - "lands". He considered federation possible and realistic through overcoming the imperial past, decentralising power and democratising local territorial governments. As a law theorist, Eichelman was a supporter of German concepts of federalism, which within the Hohenzollern empire in the second half of the $19^{\text {th }}$ century was implemented as nationalistic. He understood federalism similarly to the German concept, as a union of territories which, however, exists as a nation state.

For various Germanic nations, it was federalism that became one of the models of shaping the modern German nation. This was the basis of Eichelman's reflections on federalism. He was rather positive towards the project of Mykhailo Drahomanov Wilna Spilka (Вольный Союз - Вільна Спілка), which was one of the variants of a federational reconstruction of Eastern Europe. Like Drahomanov, he believed it was the state and statehood that preceded the shaping of the nation, and federalism could play a decisive role here. It is known that this view of Drahomanov's was justified if we take into account Georg Hegel's division of nations into "historical" and "non-historical". In general, federalism was seen as an ideology of transforming "non-historical" nations into the statehood stage.

Already after the failure of the Ukrainian People's Republic Eichelman presented a draft of the constitution, which was published in the form of a brochure

40 В.А. Потульницький, Історія української політологї̈ (Концепції державності в українській зарубіжній історико-політичній науці), Київ, 1993, р. 200.

${ }^{41}$ State Archive of the Russian Federation, f. 7008, op. 1, pap. 2, d. 19. 
in Tarnów. ${ }^{42}$ The basis of this text was the principle of national sovereignty and the idea of internal federalisation of the republic. On 30 June 1920, The Council of Ministers decided to create a Commission for the Constitution of the Ukrainian People's Republic, headed by the Foreign Minister Andriy Nikovsky. ${ }^{43}$ One of its members was his deputy, Professor Eichelman.

During the meetings of this commission, Eichelman was a proponent of federalist ideas. As evidenced by protocols, he repeated daily the statement about "consistent implementation of the democratic-republican foundations", horizontal systems of power, "two systems" of government, etc. He considered the federative-administrative system as the main one, in which each unit of the country has some specific competences granted by the government. The second in the hierarchy was the federated-political system, in which a unit of a country acquires the functions of a state power, with the exception of public affairs, which in the constitution belong to the competences of the federation. According to Eichelman, a characteristic feature of such method of governance is a division into lands, counties, communities and collectives. ${ }^{44}$

According to him, the division of power should be the cornerstone of a constitution draft. The referendum must become a tool of "federal-state control" 45 as it is the basis for implementing national sovereignty. As regards the form of power, Ukrainian People's Republic is a democratic republic. In this case, he oriented himself towards Drahomanov's federalism, which idealised the political system of Switzerland and the United States. Like Drahomanov, he proposed the division of the Ukrainian People's Republic into lands-states, which would have their own authorities. On this basis, Eichelman presented a wide-ranging project of federalisation of the Republic, where the "federalist structure" of the republic consisted of federal authorities of the nation, a federal parliament, federal administration, the federal Council of Ministers and a federal court. ${ }^{46}$ Isolating federal power of the nation as the only source of power was the result of the doctrine of "national sovereignty".

In my opinion, the main drawback of Eichelman's project was the apologetics of complete decentralisation, which, in his opinion, influences the principles for the functioning of the state power system. Indeed, in his concept the authority of state power was "reduced to zero". ${ }^{7}$

In 1921, following the emigration of the Ukrainian People's Republic's government, after the defeat of the "Winter campaign" of the Ukrainian army, Eichelman

42 О. Ейхельман, Проект Конституиії - основних державних законів Української Народної Республіки, Київ-Тарнів, 1921, р. 96.

${ }^{43}$ Central State Archives of Supreme Bodies of Power and Government of Ukraine, f. 1065, op. 2, pap. 294, ark. 6.

44 Ibid.

45 Ibid., ark. 9.

46 Ibid., f. 3382, op. 1, pap. 14, ark. 182.

47 Ibid., f. 1065. op. 2, pap. 294, ark. 15 od. 
prepared a memorandum on the redevelopment of Eastern Europe entitled Меморандум УНР и ее отношение к вопросу единства между государствами, образовавшимися на территории бывщей Российской империи, в том числе, и Новой России.$^{48}$ He perceived Russia as a country belonging to Eastern Europe. Of course, it was an attempt to respond to the Versailles-Riga system.

The theoretical basis for him was the "14 points" of the US President Thomas Woodrow Wilson, where there was talk about the law of nations to self-determination. For Eichelman, this law could have been applied only within the framework of an ethnic territory, however he did not present his vision regarding the Ukrainian ethnic territories.

He offered two variants of the remodelling of the old Romanov empire. The first, a union of independent states, with the preservation of their sovereignty and international legal organisations, such as the League of Nations. The second variant was the renewal of the "common and indivisible" federation, which will exist as a centralist state. ${ }^{49}$ Paradoxically, it follows that the League of Nations was a federation. In fact, Eichelman did not distinguish between a federation and a confederation.

Based on international law, he tried to justify the phenomenon of nation states created after the fall of the Romanov empire, although he did not explain why the Ukrainian People's Republic (as well as the Belarusian) was not recognised by Western states. This memorandum can be considered an epigonic concept, detached from the reality of the Versailles-Riga system.

The ideas of Łuckiewicz and Eichelman can be seen in a broad political context, which influenced further attempts of discussing various confederation projects during the First World War and the Russian Revolution. While Belarusian activists considered a variant of their autonomy and their country as part of a large state, Ukrainians sought autonomy and, consequently, independence. Such a sense of political dependency was permanent in Belarusians. Some activists and intellectuals tried to justify the purposefulness of another path towards statehood, however this voice was not heard.

Before the German occupation of former Russian Ukraine at the end of 1917, the circles of Ukrainian, Belarusian and Lithuanian activists actively discussed the possibility of creating a shared federation/confederation. In their vision, such a state could exist only in the form of a people's republic. The then Head of the Central Council of Ukraine Mykhailo Hrushevsky and a large part of Ukrainian revolutionaries granted Belarus and Lithuania a special role in the concept of the future political order of Eastern Europe. ${ }^{50}$ From February until April 1918, Hrushevsky

${ }^{48}$ Ibid., f. 3382. op. 1, pap. 14, ark. 287.

49 Ibid., ark. 288.

50 О. Оглоблин, “Михайло Сергієвич Грушевський”, Украйнський історик (Нью-Йорк), 1966, no. $1-2$, pp. 11-12. 
wrote about plans and negotiations aimed at creating a Belarusian-Ukrainian federation, and the Ukrainian elites were considering "shaping the federation on broader foundations, a Slavic Federation, which would include Western Slavic and Balkan countries, or a larger Black Sea Federation". ${ }^{51}$

Hrushevsky pointed out that this was how the case was presented during the work of the delegation of the Belarusian People's Republic. One of its members was the historian and professor of the Kiev University Mitrofan Dovnar-Zapol'skiy, who worked on recognising the borders between states. ${ }^{52}$ The problem of Polesye and its southern territories was the main issue of the talks, as in the imagination of Belarusians it was the "historical" border of the GDL. Dovnar-Zapol'skiy mentioned that "from the point of view of history and ethnography we in the south should not yield to anything". ${ }^{33}$ This region was also considered to be ethnographically "closer" to the central Belarusian lands than to Ukraine - in terms of rituality rather than language. Dovnar-Zapol'skiy used here his ethnographic research in Polesye. Ukrainians declared personal autonomy for Belarusians and care over the "Belarusian Piedmont", which was to be formed by three counties: Rechytsa, Gomel and Mazyr. ${ }^{54}$ However, the problem was that Ukrainian members thought in ethnic categories and suggested Ukrainisation of this area.

From the end of the Great War, recognising Belarus and Ukraine as nation states depended on the support at the international level. At the same time, the political elites of Western Europe were dominated by the belief that Ukraine and Belarus "belonged to the primordial Russian lands"

\section{Conclusions}

It is true that Łuckiewicz's federalist ideas are difficult to compare with Otto Eichelman's project. In my opinion, as a Belarusian activist he saw federalism as a political system within a large state project - the GDL. For the Ukrainian intellectual, a different approach was characteristic: Eichelman tried to use certain historical facts to justify the project of internal federalisation of Ukraine. In their political concept, it was primarily the project of a nation state, which due to the difficult international conditions can be implemented as a federation, even a multi-ethnic one. Łuckiewicz can be described as "an anticolonial intellectual", who placed every Belarusian statehood within a broad state union, bound with federational links. For him, the question of Belarusian independence depended on the freedom of the neighbouring nations. Euckiewicz believed that rebuilding the

\footnotetext{
51 М. Грушевський, “В першій делегації Української партії соц. - революціонерів (квітень 1919 р. - лютий 1920 р.)”, Борітеся - поборете!, Відень, 1920, по. 3, р. 51.

${ }_{52}$ Michaluk, Białoruska Republika Ludowa, p. 255.

53 Ibid., p. 256.

54 Ibid.
} 
whole of Eastern Europe was possible, provided that Russia's imperialism were removed through a federalisation of the region.

Eichelman had identical views. However, there was a contradiction between them: the Belarusian activist excluded Russia from Eastern European state processes, and the Ukrainian lawyer included it in the potential organisation of a union of independent states. Thus, Eichelman constructed his vision of Eastern European borders together with Russia. It could be argued that after 1918 these activists rhetorically took over the ideas of federalisation based on the principle of imperialising nations, without thinking about its implementation. Both were inclined towards federalisation, provided that Lithuania or Crimea would be part of their countries. Roman Dmowski stuck to this kind of concept; on condition that Poland was granted East Prussia or Lithuania, he also agreed to the federalisation of the country. Not to mention the Masaryk idea of Czechoslovakia as an Eastern European Switzerland. Piłsudski’s Realpolitik contained various federational ideas, which were used as a tool to shape the Eastern border of Poland.

The common feature of the federalist utopias of Łuckiewicz and Eichelman were ideological sources: the German political thought of "nationalist federation", socialist ideas, and nationalism. They also reflected the geopolitical interests in Eastern Europe and the fight against Bolshevism. The concepts of Łuckiewicz and Eichelman expressed hope for creating foundations of statehood of their countries.

\section{"Anticolonial Intellectual" Anton Euckiewicz and "Hybrid Nationalist" Otto Eichelman. A Comparative Study of Federalist Utopias Abstract}

It is not an easy task to compare Łuckiewicz federalist ideas with a project by Otto Eichelman. As a Belarusian activist, he perceived federalism as a political system within a great state project - a Grand Duchy of Lithuania. Eichelman on the other hand sought to substantiate with historical facts a project of domestic federalisation of Ukraine. In their concepts it was to be a national state which, due to difficult international conditions could be realised as a federation, even a multiethnic one. Łuckiewicz could be described as a "anti-colonial intellectual" who placed any Belarusian statehood within a broad federal union. For him, the Belarusian independence depended on the freedom of neighbouring countries. In Łuckiewicz view the transformation of the whole Eastern Europe was possible after the elimination of Russian imperialism in favour of federalisation of the region.

This opinion was shared by Eichelman. But they disagreed in one point: the Belarusian activist excluded Russian from Eastern-European statehood, while the Ukrainian lawyer included Russia in his concept of the union of independent states. It could be said that after 1918 they rhetorically adopted the formula of federalisation on the principle of "imperialising nations", without thinking of its implementation. Both of them favoured federalisation, on the condition, however, that Lithuania or the Crimea would be included in their state.

A common feature of Łuckiewicz's and Eichelman's federalist utopias were their ideological sources: the German thought of "nationalist federation", socialist ideas and nationalism. 
They responded to geopolitical interests of Eastern Europe and the struggle against Bolshevism. Łuckiewicz's and Eichelman's concepts expressed hopes for the creation of the foundations of the statehood of these countries.

\section{"Антиколониальный интеллектуал" Антон Луцкевич и "гибридный националист" Отто Эйхельман: компаративное исследование федеративных утопий Аннотация}

Сложно сравнить федеративные идеи Антона Луцкевича с проектами Отто Эйхельмана. Белорусский деятель воспринимал федерализм как политическую систему в рамках большого государственного проекта - Великого Княжества Литовского. Для украинского интеллектуала характерный был другой подход: Эйхельман пытался обосновать проект внутренней федерализации Украины, исходя из политической конъюнктуры и на основе исторических фактов. Их политические концепции это, прежде всего, проект национального государства, который мог быть реализован как федерация, на основе сложных международной ситуации того времени. Лукцевича можно определить, как «антиколониального интеллектуала", который любую белорусскую государственность рассматривал в рамках широкого государственного союза, основанного на федеративных связях. Для него вопрос самостоятельности Белоруссии зависел от свободы соседних наций. Луцкевич считал, что переустройство всей Восточной Европы возможно при условии ликвидации имперскости России по принципу федерализации этого региона.

Идентичной позиции придерживался Эйхельман. Однако между ними существовало некоторое противоречие: белорусский деятель исключал Россию из восточноевропейских государственных процессов, в то время как украинский юрист включал её в возможную организацию союза независимых государств. Следовательно, Эйхельман конструировал свое видение политических границ Восточной Европы вместе с Россией. Можно утверждать, что после 1918 года эти деятели ситуационно использовали формулу федерализации по принципу «impirealizing nations”, даже, не думая о её реализации. Оба были склонны к федерализации, при условии, что Литва или Крым войдут в состав их национальных государств. Как известно, похожей концепции придерживался Роман Дмовский, который при условии присоединения к Польше Восточной Пруссии или Литвы, тоже соглашался на федерализацию страны. Не говоря уже о идеях Томаша Масарика о Чехословакии как восточноевропейской Швейцарии. "Реальная политика" Пилсудского включала различные федеративные идеи и проекты, которые использовались как инструмент формирования восточных границ Польши в дипломатической борьбе.

Общей чертой федеративных утопий Луцкевича и Эйхельмана были идейные источники: немецкая политическая мысль о «националистической федерации”, социалистические идеи и национализм. Они также соответствовали геополитическим интересам в Восточной Европе и борьбе с большевизмом. Концепции Луцкевича и Эйхельмана выражали надежду на создание основ государственности их стран. 


\section{Bibliography}

\section{Archival and published sources}

Государственный Архив Российской Федерации, f. 7008, op. 1, pap. 2.

Центральний державний архів вищих органів влади та управління України, f. 3382, ор. 1, pap. 14; f. 1065, op. 2, pap. 294.

Lietuvos centrinis valstybès archyvas, f. 383, ap. 7, b. 56, 1.53 (улётка Грамадзяне!, люты 1916 г.)

Lietuvos Mokslų Akademijos Vrublevskų Biblioteka, Rankraščių skyrius, f. 21, b. 2069, 11. 7-8 (пратаколы беларускіх арганізацый 1917 г.)

Kalinowski W. (Łuckiewicz A.)., Kwestja Wschodnia a Białoruś, Warszawa, 1920.

Wasilewski L., "Białoruś i ruch białoruski”, Przegląd Wspótczesny, 3 (1924), no. 26.

Грушевский М.С., Освобождение России и украинский вопрос. Статьи и заметки, СанктПетербург 1907.

Грушевський М., “В першій делегації Української партії соц. - революціонерів (квітень 1919 р. - лютий 1920 р.)”, Борітеся - поборете!, Відень, 1920, nо. 3.

\section{Secondary literature}

Bergman A., "Antoni Łuckiewicz (1884-1946). Szkic biograficzny", Przegląd Historyczny, 65 (1974), no. 4, pp. 667-695.

Leonhard J., "Multi-Ethnic Empires and Nation-building: Comparative perspectives on the Late Nineteenth Century and the First World War", in: Nationalizing Empires, ed. S. Berger, A. Miller, Budapest-New York, 2015.

Michaluk D., Białoruska Republika Ludowa 1918-1920. U podstaw białoruskiej państwowości, Toruń, 2010.

Michaluk D., "Premier Białoruskiej Republiki Ludowej Antoni Łuckiewicz wobec polskich i litewskich aspiracji do Wileńszczyzny i Grodzieńszczyzny", Europa Orientalis. Studia z Dziejów Europy Wschodniej i Państw Baltyckich, 2 (2010).

Okulewicz P., Koncepcja “międzymorza” w myśli i praktyce politycznej obozu Józefa Piłsudskiego w latach 1918-1926, Poznań, 2001.

Traba R., "Historia wzajemnych oddziaływań - (niedoceniany) paradygmat w nadaniu przeszłości. Wprowadzenie”, in: Historie wzajemnych oddziaływań, ed. R. Traba, Berlin Warszawa, 2014.

Верстюк В., “Солдатенко Валерій, Революції в Україні: політико-державні моделі та реалії (1917-1920)", in: Політична історія України ХХ столітmя. У 6-ти m., vol. 2, Київ, 2003.

Ейхельман О.О., Проект Конституиії - основних державних законів Української Народної Республіки, Київ-Тарнів, 1921.

Каппелер А., Россия - многонациональная империя. Возникновение. История. Распад, Москва, 2000.

Корольов Г.О., "Українська історія Отто Ейхельмана. Імперська лояльність та служіння ‘іншій’ або 'своїй’ нації”, Архіви України, 2014, nо. 1, pp. 156-167.

Луцкевіч А., “Злучаныя Штаты ад Балтыкі да Чорнага мора”, Свабода, 1990, no. 2.

Луцкевіч А., “Палітычныя лёзунгі беларускага руху”, in: id., Да гісторыі беларускага руху, Смаленск, 2015.

Луцкевіч А., “Рэфэрат Беларускае дэлегацыі на Лязанской канфэрэнцыі народаў Расеі”, in: id., Да гісторыі беларускага руху, Смаленск, 2015. 
Міхалюк Д., “Пэр Андэрс Рудлінг, Ад Вялікага Княства Літоўскага да Беларускай Народнай Рэспублікі ідэя беларускай дзяржаўнасці падчас нямецкай акупацыі беларускіх земляў у 1915-1919 гадах", Журнал беларускіх даследаванняў, 7 (2014), no. 2, pp. 7-42.

Оглоблин О., “Михайло Сергієвич Грушевський”, Украйнський історик (Нью-Йорк), 1966, no. $1-2$.

Осташко Т.С., “Ейхельман Отто Оттович”, in: Енциклопедія історії України, vol. 3: Е-Ц̆, ed. В.А. Смолій, Київ, 2005, http://www.history.org.ua/?termin=Eykhelman_O (access: 20 April 2016).

Потульницький В.А., Історія української політологї (Конщепції державності в українській зарубіжній історико-політичній науиі), Київ, 1993.

“Собственноручные показания А.И. Луцкевича. 30 октября 1939 г., in: А. Луцкевіч, Да гісторыі беларускага руху, Смаленск, 2015.

Хаген фон М., “Империи, окраины и диаспоры. Евразия как антипарадигма для постсоветского периода”, in: Новая имперская история постсоветского пространства, ed. И. Герасимова et al., Казань, 2004.

Хаген фон М., “История России как история империи. Перспективы федералистского подхода", in: Российская империя в зарубежной историографии. Работь последних лет: Антология, Москва, 2005.

Gennadii Korolov, Senior Research Fellow in the Institute of Ukrainian History, the National Academy of Sciences of Ukraine, doctor of history. Research interests: history of historiography, the history of federalism in East Central Europe, the Ukrainian revolution 1917-1921 (hennadiikorolev@gmail.com). 